\title{
Challences Facing Tutors in the Teaching of Visual Arts Education in National Teacher Colleges in Uganda
}

\author{
Julius Ssegantebuka ${ }^{1}$, Timothy Tebenkana ${ }^{1}$, Ritah Edopu ${ }^{2}$, Patrick Sserunjogi ${ }^{3} \&$ John Bosco Kanuge $^{3}$ \\ ${ }^{1}$ Department of Humanities and Language Education, Makerere University, Kampala, Uganda \\ ${ }^{2}$ Department of Fine Arts, Makerere University, Kampala, Uganda \\ ${ }^{3}$ Department of Art and Industrial Design, Makerere University, Kampala, Uganda \\ Correspondence: Julius Ssegantebuka, Department of Humanities and Language Education, Makerere University, \\ Kampala, Uganda. E-mail: segan@cedat.mak.ac.ug
}

Received: April 6, 2021 Accepted: May 10, 2021 Online Published: May 25, 2021

doi:10.5539/jel.v10n4p51 URL: https://doi.org/10.5539/jel.v10n4p51

\begin{abstract}
The study examined the challenges faced by tutors in the teaching of the visual arts education (VAE) in national teachers' colleges (NTCs) in Uganda. The study adopted a qualitative approach where tutors' and pre-service visual arts teachers' (PVATs) views about the challenges facing them in the teaching and learning in visual arts were expressed. Data were collected from two purposively selected NTCs, and ten tutors. Yet, the 48 second year PVATs who participated in this study, were randomly selected from the many who were available. The researchers used interviews, document reviews and focus group discussions to collect data. The findings show that the challenges facing tutors in the teaching of visual arts have a great impact on what PVATs learn. Some visual art disciplines have too much content to be covered within a short period of two years. There is a general lack of teaching resources, such as art materials, tools and equipment, textbooks, and inadequate teaching space. The researchers recommended the reduction of the content of some visual art disciplines to fit the available time; provide art materials, tools and equipment as well as adequate teaching space which would allow the use of more appropriate teaching methods which would avail tutors with the opportunity to perform to their expectations in visual arts teaching.
\end{abstract}

Keywords: art disciplines, pre-service visual arts teachers, visual arts curriculum, tutors

\section{Introduction}

Tutors are tasked with the responsibility of preparing pre-service teachers who, upon graduation, are deployed to teach in secondary schools. Pre-service teacher preparation in Uganda is conducted in colleges known as National Teacher Colleges (NTCs). Pre-service teachers prepared in these NTCs graduate with a Diploma in Secondary Education (DSE), and are deployed to teach in secondary schools of Uganda. The aspiring pre-service teachers who apply and get admitted to a two-year DSE programme in NTCs are those who have completed Uganda Advanced Certificate of Education (UACE). The pre-service teachers who are admitted on the DSE programme in VAE are commonly known as Pre-service Visual Arts Teachers (PVATs). The tutors in these NTCs prepare PVATs using a Visual Arts Curriculum (VAC) discussed below.

\subsection{Visual Arts Curriculum in NTCs}

The VAC includes disciplines, such as methods in teaching art, history of art and art appreciation, and marketing. These are referred to as theory disciplines. The two-dimensional art (2D-art) includes: graphic design and studio technology, painting and studio technology, drawing and studio technology-still-life, nature study and figure drawing. The three-dimensional arts (3D-art) includes: sculpture and studio technology, pottery and studio technology, and multi-media crafts (DSE, 2002). It is this VAC, PVATs are exposed to during their two-year stay at NTCs in Uganda. The teacher preparation is punctuated with school practice conducted at every end of the academic year. Although there are new developments in the secondary school art curriculum which PVATs are being prepared to use, the NTCs' VAC has not been reviewed to include these new developments. Yet, the new development in the revised secondary school art curriculum, known as Integrated Production Skills (IPS, 2011), includes making studio technology a core visual art discipline. According to DSE, studio technology implies the science and skills of using materials and handling tools and equipment particular to a given area of 
study (DSE, 2002). Despite the importance of studio technology in visual arts learning, the PVATs are inadequately exposed to this knowledge of studio technology during their teacher preparation at colleges (Ssegantebuka, 2018).

\subsection{Teaching of Visual Arts Content in NTCs}

Ssegantebuka $(2016,2017)$ observes that although pre-service teacher education programmes use the same VAC when preparing PVATs, tutors from different NTCs exposed PVATs to different content areas in which they are knowledgeable. Quoting Breitenstein (2003), Ssegantebuka (2017) emphasises the need to adequately prepare PVATs to acquire the desired content and pedagogical skills as a way of increasing their knowledge and ability to teach art. Some practising art teachers complain that there are some visual art disciplines PVATs are exposed to by their tutors which do not relate to the art content in secondary schools. Tutors concentrate more on 2D art and teach comparatively little of the 3D art. Besides, the 2D arts which they teach are not adequately covered (Ssegantebuka, 2019; Tebenkana, 2011). When tutors decide to teach drawing (still-life and nature), multimedia, graphic design, painting and textile decoration to PVATs, they instead end up omitting human figure drawing, printmaking, and weaving. They face the challenge of scarcity of art materials, which forces them to use predominantly graphite pencils, leaving out many important dry and wet media which would equip PVATs with the knowledge of media. It can, therefore, be deduced that such teaching practices deny PVATs the opportunity to get exposed to appropriate content knowledge, and acquiring of techniques and media while still at college. In light of the above, the purpose of the study was to examine the challenges facing tutors in the teaching of VAE in NTCs in Uganda. Of particular concern was the following research question: What challenges are facing tutors in the teaching of visual arts in NTCs in Uganda?

\section{Literature Review}

Okonkwo (2014) identifies some problems art education is facing, including: shortage of qualified art teachers, inadequate teaching facilities and funding. It was also further noted that many schools do not have qualified staff to teach art as well as adequate teaching facilities. The other challenge faced in art education is the lack of art materials, tools, and equipment. Lack of studio space was also another challenge identified (Barnabas, 2005). It should be noted that PVATs cannot learn several artistic skills without art materials and tools and lack of studio space needed for practice. Quoting Mbahi (2000) and Okonkwo (2014) emphasise the misconception in the society that refers to art as non-academic because it is more of practical work. This belief affects the art teacher and aspiring art teachers' confidence, enrolment and lack of respect by the population. Inadequate curriculum planning and development is another challenge Okonkwo (2014) identifies. He observes that reviewing a school curriculum is paramount. He states that "Art programs at all levels of education need this review of curriculum" (p. 123).

Moalosi and Molwane (2008) researched the challenges faced by teachers in the teaching of design and technology education in Botswana's primary schools. The findings indicate that the Creative and Performing Arts (CAPA) programme "is so heavily loaded with different modules all combined to form one subject, and this makes it's teaching very difficult because primary school teachers have not been trained in all these subjects. Furthermore, some of these subjects, e.g., design and technology, are not currently being taught at colleges of education training primary school teachers" (p. 28). They further list resource constraints, teachers' lack of understanding of CAPA concepts and lack of ownership of the CAPA programme and problems of how to assess CAPA. No physical resources in terms of infrastructure and equipment have been provided to enable them to teach the subject as observed by Moalosi and Molwane (2008). Ngwenya (2020) carried out a curriculum review and the findings reveal that there is lack of adequate resources and learning materials, lack of funds, high costs of services and prohibitive policies that support the disconnection of social services once there is a delay in paying for the bills. Such practices are a manifestation of what art education is considered to be.

In Uganda, Margaret Trowell is believed to have started art education, when she introduced the art curriculum which was used during art teachers' preparation. This art curriculum she used for teacher preparation included: modelling, basket making, design, material and picture-making (Sanyal, 2000). In the subsequent years, Margaret Trowell retired and was succeeded by Cecil Todd who introduced a European model of instruction, which he later used during the preparation of art teachers in Uganda. Cecil Todd's European model of instruction promoted European views of representing art; distancing the local artists from what they were used to. These Eurocentric views later informed the design of a Bachelor of Education programme with art (B. Ed) (Ssegantebuka, 2017). The B. Ed programme was offered at Makerere University for some time and later transferred to Kyambogo Institute of Teacher Education (ITEK). However, due to several problems, some of which included poor coverage of content, the short period of art teacher preparation, and inadequate teacher 
preparation, the B. Ed programme was reduced to diploma level and then was sent to the then Teacher Training Colleges (TTC) as DSE (Mazinga, 1974). The challenges faced during the design of the DSE were transferred with little changes to TTCs. To date; these challenges are still evident in the teaching and learning of VAE in NTCs in Uganda.

\subsection{Theoretical Reviews}

Visual arts give PVATs a unique opportunity to understand the world they live in (Mcdougall et al., 2011). Visual arts further equip PVATs with the abilities to explore, imagine, and create what they perceive. Through visual arts, PVATs develop social skills when they collaborate on different art projects (National Art Education Association, 1994). According to Dhanapal et al. (2014), visual arts help PVATs develop confidence, communication skills; understand the learning process and the art of expressing themselves. They further observe that, "As they become more expressive, their language skills improve as they use different words to share their feelings and art creations" (p. 7). Similarly, Malley, and Silverstein (2014), argue that the arts contribute to the PVATs' development of creativity and problem-solving abilities and self-expression. Yet, Christensen and Kirkland (2009) affirm that, "the arts awaken the senses, enable encounters for discovery, stimulate wonder, cause questioning, and add dimensions of reflection" (p. 88). They further suggest that the use of art "ultimately enhances comprehension with the text" (p. 89). Stewart (2014) states that "students increasingly understand art-making as an investigative process, recognizing and using inquiry methods of observation, research, and experimentation as means for exploring their evolving interests and concerns as well as for constructing new knowledge and insights" (p. 10).

Visual arts are believed to develop the unique cognitive capabilities that foster flexible, divergent, original, fluent, and imaginative thinking. By making art, PVATs ponder multiple solutions based on information coupled with individual judgment (Newton, 2007; The Ontario Curriculum, Grades 1-8: the Arts, 2009). Studies in the visual arts enable PVATs to experience distinct ways of thinking, communicating, reasoning, and investigating. Learning in these modes increases PVATs' abilities to develop life skills, use varied approaches to problem-solving, collaborate with others and synthesise ideas (ACARA, 2010; The Ontario Curriculum, Grades 1-8: the Arts, 2009). This means that it rests upon tutors to respond to the challenges of helping PVATs to achieve the above-listed competencies. In this context, the researcher argues that the competencies mentioned above are not explicitly defined in the current VAC, an issue which has jeopardised quality learning in NTCs in Uganda. Therefore, this has prompted the researcher to take an initiative to examine challenges facing tutors in the preparation of PVATs in NTCs who, by nature of their profession, are expected to foster these competencies into the PVATs.

\section{Methodology of Research}

\subsection{General Background}

The study used a qualitative approach because the research sought visual arts tutors and PVATs' perceptions, feelings, attitudes and their personal views about the challenges facing tutors in the teaching and learning in visual arts. A case study was used as an appropriate research design for it provided the lenses through which the teaching and learning in visual arts were examined.

\subsection{Sample Selection}

The research was conducted in two NTCs purposively selected. One of the NTCs is located in the eastern region and the second NTC is located in the central region of Uganda. These are the NTCs with the biggest number of PVATs. The big number of PVATs in these NTCs was brought about by the government policy which made some NTCs specialise in humanities and others in sciences. The participants were ten tutors who were purposively selected for they had valuable information about the teaching and learning in visual arts. Being part of the main actors, tutors were in position to articulate the possible challenges they face in visual arts. The researchers recruited only those tutors who willingly signed the consent forms before participating in this research. The tutors were given pseudonyms for easy identification. They included: Saka, Badayo, Sakit, Kakama, Nakah, and Bambi. The forty-eight randomly sampled PVATs were second year students who had at least experienced both college and school contexts. Their recruitment aimed at getting information for use in triangulation purposes.

\subsection{Instrument and Procedures}

Data were collected using mainly interviews. The other methods of data collection included focus group discussions (FGDs) and document analysis. Interviews were the main instruments used on tutors in NTCs to solicit their perspectives about the challenges they face in the teaching of visual arts in NTCs in Uganda. The 
researchers mainly used semi-structured interviews for they allow the researcher and the participant to adjust questions and answers (Bryman, 2012; Fraenkel \& Wallen, 2000). The FGDs aimed at soliciting PVATs' views about the possible challenges faced in visual arts and how they affect their teaching and learning. The researchers only worked with PVATs who willingly signed the consent forms. All interviews were tape-recorded with the participants' knowledge and consent. The documents the researcher reviewed included: the college teaching timetables, the college VAC, PVATs' artworks and their results sheets.

\subsection{Data Analysis}

Transcribing of interview recordings started immediately and before the closure of the data collection process. This gave the researchers the opportunity to revisit participants for further information and clarity before leaving the field. Data were generally organised in categories to reflect the research objective. Themes were developed from the ideas that continuously transpired across the data (Scott \& Usher, 2010). The themes were carefully examined to get the fine distinctions that explained the challenges tutors face and their effect on PVATs learning in visual arts in NTCs in Uganda. The researcher relied on triangulation of data collected using documents, interview transcripts, and observations to ascertain consistency in the data and to get acquainted with the emerging issues (Gray, 2009; Stake, 1995). To ensure reliability, the researchers shared the individual coding schemes with two different experts in the arts field intending to discover a high similarity of coding schemes.

\section{Results of Research}

\subsection{Visual Arts Content in NTCS}

The findings from the review of the VAC and tutor interviews showed that the VAC draws its content from 2D arts which include: painting, drawing, graphic design, and textile decoration. The 3D arts include: sculpture, multimedia, interior design, and pottery. Yet, theory includes: the history of art and art appreciation, principles and methods of teaching art, and marketing. The review of the VAC further revealed that some visual art disciplines were heavily loaded with content. These visual art disciplines include: the history of art and art appreciation, principles and methods of teaching art, pottery making, multimedia crafts, drawing, graphic design, textile decoration, and market management. The review of the VAC showed that there is too much content to be covered within two years; a duration tutors and PVATs noted that it is not enough for adequate training. On top of art content (11 visual art disciplines), PVATs have foundation courses from Department of Education. All these study areas have to be done within two years of study. Tutors Bambi further noted with concern that "it is difficult to teach an area where you have little or no knowledge". Tutors identified a number of learning areas where they lack the required knowledge as including: jewelry, industrial processes of making pottery, wood/stone carving, interior design, textile construction, research in visual arts, and many others. The researchers found out that tutors not only had limited content knowledge, but also did not have the required facilities to use in teaching the above listed learning areas. At the same time, they confessed that some of the learning areas mentioned above, were not part of the VAC used during their teacher preparation. However, they had to teach these learning areas to their PVATs. Tutor Bambi stated that:

It is challenging to be assigned to teach visual art discipline you have never learnt during your teacher preparation or in which you have limited knowledge... because you cannot answer PVATs questions during teaching... what we end up doing is dodging the learners' questions and dictate the rest as a way of avoiding exposing your ignorance.

The tutor said this referring to the history of art and art appreciation. The practice is that when you are assigned to teach the history of art and art appreciation, you must also have to teach marketing management since in NTCs, marketing management is part of the history of art and art appreciation content. When asked how they go about the teaching of marketing management, they said that they get notes from business schools and then dictate notes to their PVATs.

There are observed new developments in the secondary school art curriculum which are not part of the VAC in the NTCs. Some of the developments include introducing studio technology as a core area of study. Yet, at NTCs, this is one of the study areas which have been ignored for years. However, for tutors to keep up with the trends and the pressures from their PVATs, they decided to adopt it in NTCs but with limited knowledge.

Besides, the way the curriculum is implemented poses a very big challenge. For instance, history of art and art appreciation is introduced to PVATs in the first term of the first year one; lasting three months; then reappears on the timetable in the first term of the second year after five months without studying it. Principles and methods of teaching art is introduced to PVATs in the second term of the first year and reappears in the second term of the second year when learners are preparing for their exit. A similar challenge happens to other visual art 
disciplines, such as painting, graphic design, and textile decoration. These visual art disciplines are all introduced in the first term of the first year and reappear on the timetable in the second term of the second year after ten months of not studying them. PVATs stated:

By the time these disciplines are taught again, we have forgotten all about what we studied in term one year one...we always ask our tutors to introduce the art disciplines again...an issue tutors find challenging...they end up ignoring our request (FGD-4).

This means that PVATs learn less than expected because as they are starting to pick information of a given art discipline being introduced to them, the term ends and then they take on another art discipline even before completing the introduction of the previous visual art discipline. In this respect, tutor Saka confessed that:

We teach very little content to our PVATs...we keep on teaching a bit of this art discipline and a bit of that art discipline...just to have a mark to present at the end of the year...it is challenging to keep track of learners' knowledge acquisition...but we have nothing to do; that's what the timetable requires us to do.

The findings also indicate that the little time tutors have to prepare PVATs is inappropriately used to teach PVATs visual art disciplines which do not relate with any visual art discipline in secondary schools where they are going to be deployed after graduation. These visual art disciplines include: multimedia crafts, interior design, and market management. These visual art disciplines were introduced with a general belief that they will equip PVATs with employable skills to be self-reliant. However, due to lack of expert tutors in multimedia crafts, interior design and marketing management, plus the limited time for teaching, the benefits of studying these visual art disciplines are minimal.

Another challenge tutors identified which interferes with the teaching and learning in visual arts, is the government policy of instructing the PVATs, with the aim of making them cadres of the ruling party. These programmes run between seven and ten days whenever they are conducted. They greatly affect the amount of content tutors are supposed to teach in a given term in which they are conducted. Tutor Badayo observed:

The government has a number of programmes dubbed "patriotism programmes" which they conduct in teacher institutions on an annual basis...these programmes include mchaka mchaka, military science and many others...they consume a lot of our time. They are compulsory for every student-teacher and they are conducted by military men and women. In other words, the government uses colleges as their experimenting ground for its programmes.

Unlike other subjects where content to be taught both at college and schools is prescribed in textbooks, the choice of art content and evaluation of art are very much in the hands of the art teacher. This is due to the different contexts. It is ideal not to restrict what to teach to particular content of particular area, because of availability and accessibility of content and exemplars. Tutors mentioned that the liberty to choose art content is challenging since some end up acting outside the curriculum and deny the PVATs the opportunity to study what they are supposed to study.

\subsection{Teaching Methods in Visual Arts Education}

Tutors observed that active teaching methods are vital in teaching and learning in visual arts. They mentioned that they use demonstration, discussion, critique and group methods. However, tutors mentioned that much as they try their level best to use active teaching methods, they are not used to their fullness. They reasoned that some of these teaching methods need much bigger space and readily available materials. For instance, tutor Sakit stated:

We need materials and tools in place if we are going to use demonstration and group discussions satisfyingly...well as we need space big enough to exhibit artworks to carry out critique as a teaching method... using learner centred teaching methods in our NTCs is still a challenge.

Some of the PVATs lamented:

when it comes to practising teaching during microteaching as well as real school practice, tutors demand that we use demonstration, discussion, and exhibition... I mean active teaching in art...well aware that we are many in class, there is no enough space and above all they did not show us how to do it (FGD-2).

These are challenging issues since NTCs lack studio spaces from which they can model the much needed active teaching methods to PVATs in the teaching and learning in visual arts.

\subsection{Teaching Resources and Infrastructure in Visual Arts Education}

The teaching resources in this study focused on art materials, tools and equipment, computers, and textbooks; 
while the infrastructure concentrated on studio space and computer laboratories. The commonest art materials provided to PVATs in the NTCs are graphite pencils, paper, and clay. The rest of the art materials are provided by the individual PVATs. On admission, PVATs are provided with a requirement form on which art materials they need in their teacher preparation are listed. Yet, tools and equipment are very scarce; and some are not available at all in some of the colleges. PVATs explained:

We find it expensive to buy art materials for ourselves.... Yet, we have to buy many art-materials...buying ourselves materials is the big challenge. Some of us do not get money for materials in time from our parents...most of the time we buy poor quality materials because they are cheap and are the ones we can afford (FGD-6).

In agreement with PVATs, tutors observed that the lack of art materials does not only affect the quality of the artworks PVATs produce but also the number of artworks they are expected to produce in a given term. Tutor Bambi stated:

You give the PVATs assignment to produce at least four artworks in a given discipline for a term, but because many get money for art materials late from their parents, they end up producing one or two artworks only for an entire academic year. This is a challenging situation because the PVATs who have produced the four pieces of artworks and the ones who have produced one artwork all have to pass.

Tutor Badayo also narrated:

We find it very hard to teach a discipline without the required materials and tools. We would use our knowledge and improvise, but some art materials cannot be substituted...for example, what should we improvise leather with...what about stone carving and wood carving?

It was also noted that lack of art materials, tools, and equipment had a big impact on tutors' practices on teaching and learning in visual arts. Tutors regarded content areas where they lacked materials, tools and equipment as irrelevant. In this regard, they did not bother teaching such content areas to their PVATs; telling them that they can do without those visual art disciplines. A few tutors, who bothered teaching such content areas, reported that they do it theoretically. Tutor Kakama explained:

We narrate to the PVATs; we tell them about the art disciplines. At times, we make promises that one time you will get to know more about these areas, we simply talk to them rather than practical engagement in the production of artworks.

When it comes to tools and equipment in visual arts teaching, tutors said that they stop at showing their PVATs YouTube videos how these tools and equipment work. At the same time individual PVATs cannot afford buying the tools and equipment. This means that PVATs train and leave colleges without acquiring skills in using some art-materials, tools, and equipment. Therefore, with no art materials, tools, and equipment, there are fewer opportunities for anticipated visual arts learning. In the same way, tutors' professional knowledge development in the said content areas and the acquisition of practical skills expected of a competent teacher are affected.

Tutors indicated that there is a general lack of textbooks. Tutor Saka noted that "We mainly use unpublished reading materials". This means that the authenticity of the unpublished materials is uncertain. This was seen as a big challenge since lack of textbooks hampers PVATs' acquisition of skills which would necessitate independent reading and conducting research in VAE.

It was observed that the studio or teaching space is inadequate. The only limited space these colleges had was used in shifts between year one and year two student-teachers. Tutor Nakah stated:

With the limited space, we cannot closely follow our PVATs while working on their projects. This is so because there is not enough space for the studio, as well as storage space... what we do is to give them assignments and wait for what they bring and we mark without many questions.

Besides, the limited space is shared among visual art disciplines. For example, you find that where painting is done, it is the same teaching space used for teaching and learning textile decoration, design, and drawing. It was, therefore, observed that a lot of time is wasted during the change-over from, say, painting to textile decoration or sculpture. In the same vein, tutors mentioned that cleanliness is hard to maintain since some visual art disciplines use messy materials.

Both teachers' college under the study had a computer laboratory from which PVATs would go for computer literacy. Apart from the pre-service teachers who offer computer science as a teaching subject, PVATs go to computer laboratory for general introduction only. What is challenging though, the introduction to computer literacy for PVATs lasts for only one week. PVATs lamented: 
The one week we were given for introduction to computer literacy just raised our anxiety...Due to fewer working computers compared to the number of PVATs who needed to use them, we had limited access...we spent most of the time following the instructor who demonstrated to us using the projector (FGD-1).

This meant that PVATs' limited access to computers denied them the opportunity to acquire skills on how to use computers to search for information. As a result, tutors found it had to assign research work to the PVATs which would necessitate them to use computers.

\subsection{Assessment Structure in the Visual Arts}

Another challenge tutors envisage is the administering examinations to PVATs at the end of the academic year after being away from college for three months. After the three months' period of which part is their holidays and another part is their school practice, they return to colleges for end-of-year examinations. PVATs explained:

When we return to colleges for examinations after school practice, we normally have very little time for revising in preparation for the end-of-year examinations... Because between end of school practice and beginning of end-of-year examinations, there is a space of only two weeks which is not enough time to revise as well as prepare for end of year exhibition examinations (FGD-4).

PVATs further noted:

Although we spend this period in secondary schools engaged in school practice, there is very little we do that informs what we are likely to be examined... many of us were assigned other responsibilities on top of teaching. The responsibilities we are given cost us a lot of time...we are given many lessons as well as being sports masters, prep masters, and at times warden (FGD-2).

The practice of sending PVATs to schools for school practice before end of year examinations has for long affected their performance. Thus, they are tagged as the poorest performing group at NTCs since they lead in getting retakes.

As a follow-up on the challenges tutors face in the teaching in visual arts, the researchers found out that in the entire academic year, PVATs do only one question from the 2D category and one from the 3D category. For example, PVATs select only one question from painting, textile, or drawing. The same applies to 3D where PVATs select one question from pottery, sculpture, or multimedia. However, for PVATs to be examined in only two art disciplines out of the 11 art disciplines they study in an entire academic year seemed not to be comprehensive enough. The tutors raised the need to assess their PVATs in more study areas, but the assessment structure does not allow them. They end up following what they do not believe in.

Tutors noted with concern that the college 57mphasizes summative assessment in which PVATs are allowed to exhibit coursework done throughout the academic year for examinations. Such practice encouraged double marking of artworks. Tutors also mentioned a notable challenge they are facing. This is the policy of marking the exhibition examination for only one day. As a policy, tutors have only eight hours of a given day within which to mark and pull down the exhibition. Surprisingly, this policy does not consider the number of PVATs who exhibit. As a result, tutors end up marking for the sake of having a mark for PVATs other than critically assessing artworks for the benefit of the learners.

\subsection{Attitude Towards Visual Arts Education}

Attitudes for both PVATs and tutors were mentioned as posing challenges during the teaching and learning in VAE. Tutors observed that PVATs with negative attitude do not perform well in visual arts. They dodge lectures and always produce art works for the sake of having something to present. In the same manner, tutors' attitude towards the art subject influences what and how the tutors will teach. Therefore, belief and attitude have a greater effect on visual arts. Tutor Biina stated:

The society looks at art as a subject for the talented but academically weak. This is a long-standing belief that has existed since the colonial times. The teaching of art has long been taught with no theory hence the belief that art is not academic because it is more of practical.

Tutor Nakah also observed:

The missionaries who started schools based on Western education in Uganda used to recommend art and any other technical or vocational subject to students who failed to qualify for admission to prestigious courses, such as engineering, architecture, medicine, and law. [They were instead] channeled to education. They joined education not by their wish but by the system or by their parents. In this case, these students studied with low levels of interest. 
Such attitudes have negatively affected artists and art teachers' confidence. They have been made to feel academically inferior.

\subsection{Other Challenges Faced in Visual Arts Education}

Understaffing was another big challenge tutors and PVATs mentioned. According to tutor Saka, "a well-staffed art department is supposed to have six full time tutors". However, of the two NTCs visited, one college had four tutors, but only two were full time tutors. College two had only two full time tutors with one part time tutor. This means that many visual art disciplines lacked tutors in charge and what PVATs used to do was to find ways of getting notes from their friends from other colleges and a few from universities. One PVAT explained:

For the art disciplines where we do not have tutors, we depend on our friends' notes they get either from other NTCs or universities...the challenge we face is about understanding some of these notes, because we were not in class when they taught our friends...at times the handwriting from our friends is horrible...(FGD-6).

Some PVATs mentioned:

Some of our tutors are caring...they give us assignments in art disciplines where we do not have tutors. They can tell you that you go and use your A-Level knowledge and print a textile or model a family in clay or an angry man...but the unfortunate part is that they do not mark what we do (FGD-3).

Tutor Kakama stated:

Having fewer tutors in the subject of art to me is not a big problem...you simply tell the PVATs to draw a still life, nature, or tell them to go and paint what they want to paint. Art is not like history that you have to read notes to the class as they are writing. For me, I do not consider understaffing as a big challenge to discuss here...

Late payment and travelling long distances to the work places de-motivated tutors and contributed to the skipping of some content they would teach. At times, tutors would fail to report for duty since they had no money for transport. This negatively affects their performance to an extent that PVATs start developing a negative attitude towards them. One PVAT stated:

It seems our tutors are too old... a tutor might come late and it takes him or her one to two hours resting from a long distance. By the time he or she is through with resting, the time is gone and we have to go for other subjects like psychology, philosophy in education department...we end up missing because it happens whenever these tutors come to teach... (FGD-1)

PVATs mentioned the weak administration as one of the challenges faced at college during teacher preparation. One PVAT stated:

When the administration is not closely supervising tutors, they can decide to do whatever they find easy and time saving on their side...some of our tutors can attend to their lectures four times in a term but we have never heard one being questioned for that...the practice is simply spreading even to others who used to attend regularly... (FGD-4)

In this kind of situation, PVATs stand high chances of missing out on quality engagement with the required visual arts content.

\section{Discussion}

The findings presented show that the challenges facing tutors in the teaching of visual arts are posing a great impact on what PVATs learn. The review of the VAC shows that it draws content from 2D, 3D, and theory of which some art disciplines were mentioned as having too much content to be covered within two years as observed by Moalosi and Molwane (2008). It was also revealed that PVATs do not only study art content during their preparation, but also study foundation courses which introduce them to how to teach. This explains why tutors find it hard to cover the required art content for adequate teacher preparation. As a way of covering a considerable amount of art content tutors end up rushing their PVATs by giving them take-home assignments (Saka, in interview, 2020).

The results of the study show that tutors had limited content knowledge in some of the learning areas, such as jewelry, industrial processes of making pottery, wood/stone carving, interior design, textile construction, and research in visual arts. Some of the learning areas mentioned above, were not part of the VAC used during their teacher preparation. It was also observed that tutors did not have the required facilities to use in teaching the above listed learning areas. However, regardless of having limited knowledge in these visual art disciplines and 
lacking the required facilities to use in teaching, management went ahead and assigned tutors to teach these visual art disciplines. As a result, the tutors ended up dictating for their PVATs what content they should study regardless of what is stipulated in the visual arts programme (Ssegantebuka, 2017, 2019).

The findings of the study reveal an incoherency in the way the curriculum is implemented. Some visual art disciplines are introduced in the first term of the first year and then reappear on the timetable in the second term of the second year, after ten months without studying them (Sendagire, in interview, 2020). Tutors observed that by the time these art disciplines are re-introduced their PVATs have forgotten all about what they studied when they were first introduced to them. This means that PVATs learn less than expected because they take too long before these visual art disciplines are timetabled again. Tutors further noted that the back and forth teaching hampers their ability to track their PVATs' knowledge acquisition as observed by Tebenkana (2011). Therefore, tutors' practices do not only deny PVATs in-depth engagement in VAE, but it also perpetuates inadequate teacher preparation in NTCs in Uganda.

Although tutors mentioned that they use active teaching methods, they do not use them to their fullness. They explained that this is so because they have limited teaching space and they also lack art materials needed for some of the active teaching methods to be employed. They observed that for some active teaching methods, they need studio space big enough to exhibit artworks to carry out critique as a teaching method. This means that PVATs do not acquire the abilities to use active teaching methods while still at college. Yet, Clark and Starr (1986) urge that exposing PVATs to active teaching methods, while still at college, helps them learn selecting instructional materials appropriate to given content.

It was found out that the NTCs do not provide art materials, tools, and equipment to their PVATs. It is up to individual PVATs to provide their art materials. However, very few PVATs could provide themselves with the art materials and none of the PVATs could buy the required amount of art materials. Therefore, the lack of art materials, tools and equipment does not only affect the quality of the artworks PVATs produce but also the number of artworks they are expected to produce in a given term. In this case, the differences in the quality and quantity of the art materials individual PVATs buy has always had a big impact on what PVATs learn. Therefore, lack of art materials, tools, and equipment has been observed by Moalosi and Molwane (2008) as a resource constraint affecting both PVATs and their tutors.

It was observed that the studio or teaching space was inadequate. The only limited space these colleges had was used in shifts between year one and year two student-teachers. Findings reveal that the limited teaching space was used for instructional purposes after which PVATs are let loose to find where they can work from to produce the assigned artworks. Tutors noted that the limited space denied them the opportunity to closely supervise PVATs while working on their projects. This is in agreement with Barnabas (2005) who identified lack of studio space as a big challenge in teaching visual arts. It should, therefore, be noted that when tutors do not guide the practical production of the artworks, PVATs are likely not to develop the manipulative and practical skills they need in VAE.

The PVATs in these colleges had limited access to computers. This was due to fewer working computers compared to the number of PVATs who needed to use them. Therefore, limited access to computers denied PVATs the opportunity to acquire skills on how to use computers to search for information. As a result, PVATs find themselves entirely depending on their tutors for notes (Bayo, in interview, 2020).

The results of the study further reveal that there are policies which greatly impact on tutors' performance and PVATs' learning in visual arts. The policies focuses on summative assessment compared to formative assessment (Ssegantebuka et al., 2021). The structure of examinations gives PVATs opportunity to attempt only two questions from two art disciplines out of the 11 art discipline. PVATs are instructed to choose one question from the category of 2Ds and one question from the category of 3Ds in an entire academic year (Ssendagire, in interview, 2020). There is also a policy of marking of the exhibition examination for only one day. This explains the ambiguity tutors exhibit as far as assessment in visual arts is concerned. These policies ignore the tutors' need to critically and analytically mark PVATs' art works. As a result, tutors end up marking for the sake of having a mark for PVATs other than critically assessing artworks for learners' acquisition of the desired content knowledge.

Attitude negatively affects tutors and PVATs teaching and learning, respectively. When PVATs have negative attitude, their performance is also affected negatively. Their attendance is always irregular, thus, affecting concentration on studies. The causality of the negative attitude is linked to the misconceptions in the society that refers to art as an inferior and non-academic subject, as observed by Okonkwo (2014).

Understaffing was a big challenge which affected tutors teaching as well as PVATs' learning as observed by 
Okonkwo (2014). Of the two NTCs covered during the study, none had the required number of tutors per given department. As a result, some tutors were assigned to teach visual art disciplines they are not comfortable with due to limited knowledge (Ssegantebuka, 2017). In this case, the few tutors who were in these NTCs were overloaded with visual art disciplines. Thus, understaffing, which results in overloading was observed by Ssegantebuka (2017) as one of the main causes of poor content coverage.

It was observed that late payment and travelling long distances to the work places de-motivated tutors and affected their performance (Ssendagire, in interview, 2020). Tutors confessed that this contributed to the skipping of some content they would teach. At times, tutors fail to report for duty since they have no money for transport. It was also observed that some tutors can afford appearing twice or thrice in a term for lectures which leads to inadequate teacher preparation.

\section{Conclusion}

The college administration together with the Ministry of Education and Sports should either reduce the content of some visual art disciplines which is currently said to be too much to fit in the available time by concentrating on major topics or extending PVATs' stay at college from two to three years. In the same way, they should allow PVATs to specialise in fewer visual art disciplines instead of learning all. Specialisation will allow PVATs in-depth learning. Besides, the college administration should allocate time based on the peculiarity of a given visual art discipline for adequate handling. The VAC developers should also ensure coherency in the teaching of visual arts by distributing the visual art disciplines in a manner that supports knowledge connections.

The college administration should provide art materials, tools, and equipment to ensure for quality and quantity. It will be easy to talk about quality and quantity, at the same time PVATs will be in a position to produce the given number of artworks and in time. The availability of art materials and tools improves PVATs' content coverage and knowledge acquisition.

The college administration together with the Ministry of Education and Sports need to provide adequate teaching space to art departments. The availability of the adequate teaching space permits the use of active teaching methods, such as exhibition and critiques and formative assessment. With adequate teaching space, PVATs improve their practice as well as their theoretical knowledge. Additionally, the provision of adequate teaching space will permit tutors to critically and analytically mark exhibition examinations, since the space for the exhibition will be at their disposal and not shared with other subjects as it is currently.

The Ministry of Education and Sports should recruit more tutors based on the required staff establishment in the art department. The availability of the required number of tutors lessens the burden of overloading the few tutors available. In the same way, the colleges are likely to get expert tutors in different visual art disciplines which can result in improved teaching and improved learning.

Improved remuneration coupled with provisional of accommodation near tutors' workplaces are likely to motivate tutors, thus, improving their performance. Motivated tutors by all means work tirelessly to see their PVATs positively improve the way they learn which results in acquiring the desired content knowledge. Timely remuneration and provisional of accommodation near the workplace does not only motivate tutors but also improves on tutor presence and attendance to their obligations. This means that tutors will be able to supervise the process of producing artworks done by their PVATs right from prototyping, thus, improving teacher preparation in NTCs in Uganda.

\section{Acknowledgement}

The authors are deeply grateful and appreciate the financial support from the Government of Uganda through Makerere University Research and Innovations Fund.

\section{References}

Australian Curriculum, Assessment and Reporting Authority (ACARA). (2011). The shape of the Australian curriculum: The arts. Retrieved from http://www.acara.edu.au

Barnabas, S. D. (2005). Teachers' assessment of children creative artwork: Case study of some primary schools in Kaduna State. Unpublished master's thesis. Department of Fine Arts, A. B. U., Zaria.

Breitenstein, G. (2002). A comparison of Texas pre-service teacher education programs in art and The 1999 National Art Education Association's standards for art teacher preparation. Doctoral dissertation, University of North Texas.

Bryman, A. (2012). Social research methods (4th ed.). Oxford University Press. 
Christensen, L. M., \& Kirkland, L. D. (2009). Early childhood visual arts curriculum: Freeing spaces to express developmental and cultural palettes of mind. Childhood Education, 86(2), 87-91. https://doi.org/10.1080/00094056.2010.10523119

Clark, L. H., \& Starr, I. S. (1986). Secondary and middle school teaching methods. McGraw-Hill School Pub Co.

Dhanapal, S., Kanapathy, R., \& Mastan, J. (2014). A study to understand the role of visual arts in the teaching and learning of science. Asia-Pacific Forum on Science Learning and Teaching, 15(2), 1-25. Retrieved from http://nbn-resolving.de/urn:nbn:de:0111-pedocs-165544

Diploma in Secondary Education. (2002). Art and craft module AC/3. Kyambogo University.

Fraenkel, J. R., \& Wallen, N. E. (2006). How to Design and Evaluate Research in Education (4th ed.). McGraw-Hill.

Gray, D. E. (2009). Doing research in the real world (2nd ed.). Sage Publications.

Malley, S. M., \& Silverstein, L. B. (2014). Examining the intersection of arts education and special education. Arts Education Policy Review, 115(2), 39-43. https://doi.org/10.1080/10632913.2014.883894

Mazinga, K. (1974). The development of art education in secondary schools in Uganda. Unpublished master's thesis. Makerere University.

Mbahi, A. A. (2000). Art teacher. Kingswell Publishers Ltd.

Mcdougall, M. B., Bever, \& Seper, R. (2011). Art as a Way of Knowing. Exploratorium, 1-33.

Moalosi, R., \& Molwane, O. B. (2008). Challenges facing teachers in the teaching of design and technology education in Botswana's primary schools. Design and Technology Education: An International Journal, 13(3).

National Art Education Association. (1994). The National Visual Arts Standards. Reston. Retrieved from http://www.arteducators.org/store/NAEA_Natl_Visual_Standards1.pdf

Newtown. (2007). Art curriculum standards grades 1-12 Newton public schools adopted by the board of education. Retrieved from http://www.newtown.k12.ct.us/.../Newtown/.../Curriculum\%20Documents/

Ngwenya, V. C. (2020). Curriculum implementation challenges encountered by primary school teachers in Bulawayo Metropolitan Province, Zimbabwe. Africa Education Review, 17(2), 158-176.

Okonkwo, I. E. (2014). Towards quality art education: Challenges and opportunities. Unizik Journal of Arts and Humanities, 15(1), 110-130. https://doi.org/10.4314/ujah.v15i1.6

Ontario Ministry of Education and Training. (2009). The Ontario Curriculum, Grades 1-8: The Arts.

Sanyal, S. K. R. (2000). Imaging art, making history: Two generations of Makerere artists. Doctoral dissertation. Emory University.

Scott, D., \& Usher, R. (2010). Researching education: Data, methods and theory in educational enquiry. Bloomsbury Publishing.

Ssegantebuka, J. (2016). Tutors' knowledge-base and the preparation of pre-service visual arts teachers in Uganda. Unpublished doctoral thesis. Makerere University.

Ssegantebuka, J. (2017). The relevance of the visual arts curriculum in the preparation of pre-service visual arts teachers in Uganda. Problems of Education in the 21st Century, 75(4), 394-409. https://doi.org/10.33225/pec/17.75.394

Ssegantebuka, J. (2018). Pre-service visual arts teachers' perceptions of their experiences of school practice: A case of national teacher college in Uganda. Academic Journal of Interdisciplinary Studies, 7(1), 45-45. https//doi.org/10.2478/ajis-2018-0004

Ssegantebuka, J. (2019). The influence of different educational contexts on tutor presentations of visual arts in teacher colleges in Uganda. Problems of Education in the 21st Century, 77(4), 515.

Ssegantebuka, J., Sserunjogi, P., Edopu, R., Tebenkana, T., \& Kanuge, J. B. (2021). In-service teachers' perceptions of the effectiveness of their pre-service art education program in Uganda. Problems of Education in the 21st Century, 79(1), 118-132. https://doi.org/10.33225/pec/21.79.118

Stake, R. E. (1995). The art of case study research. SAGE Publications.

Stewart, M. G. (2014). Enduring understandings, artistic processes, and the new visual arts standards: A close-up 
consideration for curriculum planning. Art Education, 67(5), 6-11. https://doi.org/10.1080/00043125.2014.11519285

Tebenkana, T. (2011). Efficacy of the distance education mode in the training of art and design teachers at Makerere University. Unpublished doctoral thesis. Makerere University.

\section{Copyrights}

Copyright for this article is retained by the author, with first publication rights granted to the journal.

This is an open-access article distributed under the terms and conditions of the Creative Commons Attribution license (http://creativecommons.org/licenses/by/4.0/). 